\title{
MODELLING PRODUCTIVITY OF CROPS IN SHORT CROP ROTATION AT IRRIGATION TAKING INTO ACCOUNT AGROECOLOGICAL AND TECHNOLOGICAL FACTORS
}

\section{Markovska O. Ye.}

\section{INTRODUCTION}

Obtaining of high and qualitative yields under the diminished watering and irrigation norms is an actual problem of innovative irrigation technologies in Ukraine and many other countries of the world. In this direction, numerous decision support tools have been developed over the last decades in the field of irrigated agriculture, which have provided an opportunity to regulate the consumption of irrigation water and other resources per unit of crop production ${ }^{1}$.

This scientific and practical direction allows solving the problem of application of the newest irrigation methods all over the world taking into account natural-climatic and economic indexes. As a result, special computer programs have been developed directed to the information support of irrigated agriculture, but unfortunately, they have not yet been widely implemented in the production conditions of Southern Steppe of Ukraine ${ }^{2}$.

Therefore, an important scientific and practical task is to adapt the latest computer technologies to the local conditions of the farms and irrigation systems from the point of view of optimization of crop cultivation technologies, primarily tillage systems, fertilization, plant protection, irrigation regimes, etc. Such innovative approaches at the expense of the use of mathematical models will allow estimation of

${ }^{1}$ Ahmadi H., Mosallaeepour E., Kamgar-Haghighi A.A. Modeling Maize Yield and Soil Water Content with AquaCrop Under Full and Deficit Irrigation Management. Published on the 28 of March 2016. URL: https://link.springer.com/article/ 10.1007/s11269-015-0973-3 (дата звернення: 25.10.2017).

${ }^{2}$ Вожегова Р.А., Лавриненко Ю.О., Коковіхін С.В., Писаренко П.В. та ін. Інструкція по оперативному розрахунку поливних режимів та прогноз поливів сільськогосподарських культур за дефіцитом вологозапасів: науково-методичні рекомендації. Херсон: ВЦ І33, 2012. 54 с. 
different scenarios for irrigated agriculture and choice of the optimal combination of technological operations to save resource expenditures, obtain economically feasible levels of yields and solve environmental problems of agricultural production.

\section{Scientific bases and practical tools for modeling water use and crop yields in short crop rotations}

At the moment, there are many imitation crop productivity models that can be used to evaluate the effectiveness of irrigation in crop rotations with different degrees of saturation with grain, industrial and other crops under biologically optimal and water-saving irrigation regimes, which will greatly improve the efficiency of irrigation water, fertilizers and pesticides use at the level of each field, crop rotation and farm. The imitative models of plant growth and development that can be created in the DSSAT and CROPWAT software complexes are of practical importance, however, none of these programs allows controlling soil fertility parameters, its ecological and meliorative conditions and optimize crop rotation on the basis of a comprehensive analysis of the initial data. One of the strategic solutions to these problems was the development of the United Nations FAO (Food and Agriculture Organization) Division of Land and Water Resources, a special software complex, AquaCrop, which is designed to simulate water and nutrient expenditures for the formation of programmed yield levels, to establish the optimal response and resource-saving irrigation by different biological parameters of crops, study the impact of meteorological factors on plant production processes, etc. ${ }^{3}$.

This simple and reliable model has been successfully tested for many cereals, industrial and forage crops in different regions of the world (for example, barley - in Southern Sahara region of Africa, wheat - in Iran and western provinces of Canada, forage crops - in Ethiopia, corn for grain - in California (USA) et al.). $)^{4,5,6,7}$.

${ }^{3}$ Raes D., Steduto P., Hsiao T.C., Fereres E. AquaCrop training handbooks. Running AquaCrop. 2017. Book 2. Chapters 3-7. P. 19-61.

${ }^{4}$ Adger N., Wreford A., Hulme M. Strategic Assessment of the Impacts, Damage Costs, and Adaptation Costs of Climate Change in Europe. Adaptation and Mitigation Strategies: Supporting European Climate Policy (ADAM project). Tyndall Centre for Climate Change Research. 2003. Technical Report № 7.20 p. 
Many studies have been conducted in arid regions using the AquaCrop model to optimize grain yield and herbage mass using water-saving or biologically optimal irrigation. For example, Farahani and Garcia-Vila used AquaCrop in 2009 for bio-optimal and watersaving irrigation in Syria and Spain, Salem, etc., in 2011 for winter wheat in resource-saving irrigation - in arid regions of Iran, Iraq etc. in 2010 - for barley in different regions of Ethiopia ${ }^{8,9,10}$.

The AquaCrop software and information system achieves the optimal balance between the simplicity of data entry, accuracy and reliability, which are aimed at studying the dynamics of basic and very complex biophysical processes to guarantee accurate modeling of the plant-soil crop reactions. AquaCrop can be used as a strategic planning tool or for short-term forecast and for the provision of assistance to agronomists in management decisions for both irrigated and non-irrigated agriculture.

Practical use of AquaCrop has great advantages in such cases:

- study of the response of crops to environmental changes (training tools);

${ }^{5}$ Fritz B. K., Kirk I. W., Hoffmann W. C., Martin D. E. Aerial application methods for increasing spray deposition on wheat heads. Applied Engineering in Agriculture American Society of Agricultural and Bigical Engineers. 2006. Vol. 22(3). P. 357-364. URL: http://ddr.nal.usda.gov/bitstream/10113/1926/1/ IND43877934.pdf

6 McCarthy N. Understanding agricultural households' adaptation to climate change and implications for mitigation: land management and investment options. Integrated Surveys on Agriculture. Washington D.C., USA: LEAD Analytics Inc. 2011. P. 42-47.

7 Milton C., Chamala S. Conservation Tillage and Cropping Innovation: Constructing the New Culture of Agriculture. Iowa State University Press. 2008. URL: http://onlinelibrary.wiley.com/book/10.1002/9780470290149 (дата звернення: 27.02.2018).

${ }^{8}$ Araya A., Solomon H., Kiros M.H., Afewerk K., Taddese D. Test of AquaCrop model in simulating biomass and yield of water deficient and irrigated barley (Hordeum vulgare). Published on the 1 November 2010. URL: http://www.sciencedirect.com/ science/article/pii/ S037837741000226

${ }^{9}$ FAO IRRIGATION AND DRAINAGE PAPER by Pasquale Steduto (FAO, Land and Water Division, Rome, Italy) T. Hsiao (University of California, Davis, USA) Elias Fereres (University of Cordoba and IAS-CSIC, Cordoba, Spain) D. Raes (KU Leuven University, Leuven, Belgium). FOOD AND AGRICULTURE ORGANIZATION OF THE UNITED NATIONS. Rome, 2012. № 66. P. 70-85.

${ }^{10}$ García-Vila M., Fereres E., Mateos L., Orgaz F., Steduto P. Deficit irrigation optimization of cotton with AquaCrop. Published on the 22 of May 2008. URL: https://dl.sciencesocieties.org/ publications/aj/abstracts/101/3/477 
- comparison of modeled and actually harvested crops at each field, crop rotation, farm or region;

- identifying factors that limit agricultural production output and irrigation productivity (benchmarking tools);

- development of a strategy in the conditions of water scarcity in order to maximize the productivity of irrigation water and use of resource-saving irrigation regimes;

- choice of a strategy of artificial humidification: biologically optimal, water-saving, soil-protective;

- adjusting the time of sowing (planting), selection of varieties (hybrids), optimization of the fertilization system, efficiency of mulch use, water accumulation from atmospheric precipitation (methods and practices of management of agro-production systems);

- study of the impact of climate change on crop production, comparing meteorological parameters over the past years and forecasting for the future;

- strategic planning, multivariate analysis, local modeling that can be carried out by agronomists, hydraulic engineers, economists, water management officials, scientists, graduate students and students.

It should be mentioned that there are some limitations to the use of this system: daily biomass accumulation rates and programmed yield levels are modeled only for a limited number of crops that have a single cycle of growth and development. Yield forecasting is intended for the local field level (point modeling) with a clear account of the constituents of irrigation systems on irrigated lands based on the control of such indexes as: precipitation, irrigation regimes (watering and irrigation norms, number of watering, calendar dates for watering, etc.), capillary lift, evaporation from the soil surface and transpiration by plants (evapotranspiration), movement of moisture deep into the soil profile where it becomes inaccessible to the root system of plants, etc. ${ }^{11}$.

Although the AquaCrop algorithm is designed on the basis of complex biophysical processes, users need only to enter a relatively small number of parameters to adapt the program to different soil and climatic conditions and crops.

${ }^{11}$ Karlen D. L., Shannon M. C., Schneider S. M., Amerman C. R. Using Systems Engineering and Reductionist Approaches to Design Integrated Farm Management Research Programs. Jour. of Prod. Agric. 1994. Vol. 119. P. 144-151. 
The AquaCrop software and information system provides the possibility of planning and operation management of irrigation, as well as other technological operations, which allows to optimize the system of irrigated agriculture at the farm level.

You have to determine the irrigation method in advance, because it affects the simulation of the water balance in the soil (i.e., evaporation from the percentage of the humidified soil surface) ${ }^{12}$.

Using AquaCrop instruments to model individual elements of crop technology in irrigated crop rotation, you must enter:

$>$ the percentage of the increase/decrease in $\mathrm{CN}_{\text {soil }}$, which have occurred through the use of different ways and depths of tillage in separate fields of crop rotation;

$>$ agro-measures that prevent surface runoff. When, for example, the irrigation regime consists of the distribution of water with small norms on separate micro-sections by the means of drip irrigation, then the parameter - "surface discharge" should be switched off;

the creation of furrows or shafts on the surface that block the surface runoff and store increased volumes of irrigation water over certain sections of the field, such as in the case of rice checks;

$>$ mulching - AquaCrop program models the reduction of evaporation when mulch covers the soil surface. Such mulch can consist of organic plant residues, special synthetic films, plastic or any other materials, which reduces the evaporation of the soil, raises its temperature in the early stages of organogenesis, prevents the mass development of weeds, etc .;

$\nabla$ the degree of the soil surface covergae by plants (in percents) at different stages of their growth and development ${ }^{13}$.

From the point of view of optimization of the crop fertilization system in crop rotation and increase of soil fertility, modeling of stress caused by the nutritive elements deficit through the nutrient balance and constructing a model of soil nutrition is of great scientific and

${ }^{12}$ Steduto P., Hsiao T.C., Raes D., Fereres D. AquaCrop - The FAO Crop Model to Simulate Yield Response to Water: I. Concepts and Underlying Principles. Agr. Jour. 2009. Vol. 101(3). P. 26-37.

${ }^{13}$ Raes D., Steduto P., HsiaoT.C., Fereres E. AquaCrop Reference manual. Running AquaCrop. 2012. Book 1. Version 4.0. Chapter 1-3. P. 1-39. 
practical importance. Because the program does not simulate nutrient cycles and nutrient balance dynamics, but only simulates the impact of stress on plant development and biomass production, the system provides an opportunity to adjust the response of crops to changes in soil fertility parameters ${ }^{14}$.

Such negative phenomena can lead to a sharp decrease in yield, deterioration of quality, decrease of economic efficiency, occurrence of environmental problems in the soil.

\section{Models of crop production process in the crop rotations at irrigation for the optimization of agricultural technologies at field levels, crop rotation, enterprise}

In order to adapt the AquaCrop program to the conditions of Southern Steppe of Ukraine, we modeled the parameters of the agroproduction system and compared the scenarios of corn grain productivity, soybean, winter barley by the amount of irrigated water used, fertilizer consumption and programmed yields at the level of the fields of a short crop rotation. The experimental data and local conditions of Research Farm "Askaniiska" of the Institute of Irrigated Agriculture of NAAS for the period of 2011-2016 were used for modeling.

The input indexes concerning temperature data, amount of precipitation, wind speed and duration of sunlight for AquaCrop were Internet resource data ${ }^{15}$. Reference evapotranspiration was calculated by using the CROPWAT software and information complex ${ }^{16}$.

The resulting information was subsequently imported as a formatted file and uploaded to the AquaCrop database. The average annual $\mathrm{CO} 2$ concentration was obtained from the program database over historical time ranges of atmospheric $\mathrm{CO} 2$ concentrations with periodic measurements at the Mauna Loa Observatory in Hawaii. As a result of downloading this input data, the program generates graphical blocks of atmospheric precipitation, reference evapotranspiration, air

14 Drought-resistant soils optimization of soil moisture for sustainable plant production. Sales and marketing group FAO UN. Rome, Italy. 2007. 96 p.

15 The archive of weather in Kherson for the period of January, 1, 2005 to December, 31, 2016. URL: https://rp5.ru/Архив_погоды_в_Херсон.

16 CROPWAT 8.0 for WINDOWS. URL: http://www.fao.org/nr/water/ infores_databases_cropwat.html 
temperatures and $\mathrm{CO} 2$ concentrations, which provides a possibility to analyze the meteorological conditions that occur in a certain year.

For the modeling of the cultivation technologies constituents, irrigation water consumption rates, fertilizers and other resources, as well as productivity levels of crops in short crop rotation at irrigation, the input databases were formed. For each crop, sowing rate, 1000 seed mass, seed germination, row spacing, plant spacing calibration was performed.

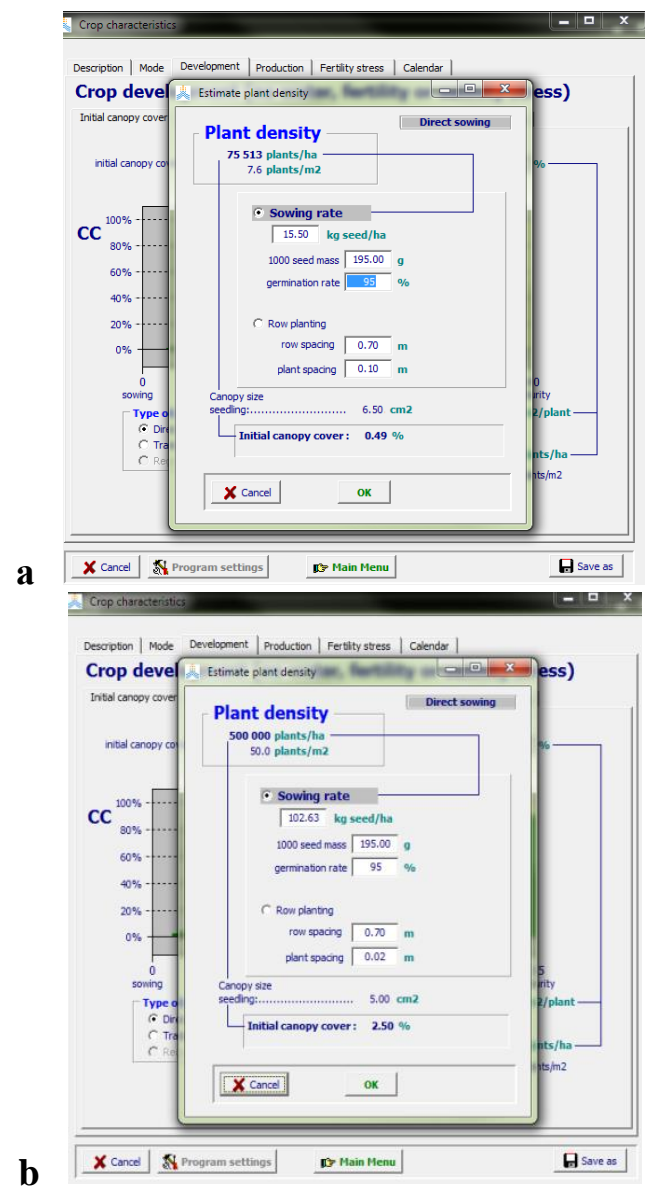

Fig. 1. A copy of the AquaCrop program screen with the calibration of the plant densities for corn (a) and soybean (b) 
Figure 1 shows a copy of the calibration screen for the plant densities of corn and soybean on the experimental plots. After entering these characteristics, the program automatically calculates the plant density of crops and the size of the "cover" of the crop - CC. The sowing date in our study coincided with the starting date of the simulation, that is, the beginning of the growing season of the crops in the crop rotation.

Further, we adjusted the parameters about the number of days from the first day after sowing to the moment of seed germination (emergence), from the first day after sowing to the date of formation of maximum leaf-stem mass - "maximum canopy" (max canopy), from the first day after sowing to the date of crop maturity - senescence, from the first day after sowing to the date of full maturity of the crop, as well as the data on the duration of flowering stage for each crop of the short crop rotation.

Taking into consideration that intensive crop cultivation technologies were used in the studied short crop rotation, the possibility of mulching of the soil surface on the fields was not indicated in the block of the soil fertility management program (Fig. 2a). Soil fertility was determined at the level of optimal parameters.

The stress from the effect of weeds on the crop development was conditionally set at the level of 3\% througout the whole vegetation period (Fig. 4, b), which is connected with the use of an integrated plant protection system, which provides highly efficient weed control.

The required water-physical characteristics of the dark-chestnut soils were taken from the field measurements (minimum field moisture content, wilting points) and compared with the soil texture class characteristics of the AquaCrop database according to the properties of the local middle-loamy soils at three soil levels.

The groundwater on the studied irrigated array are at the depth of more than $18 \mathrm{~m}$, so they do not affect the water regime of the active (estimated) soil layer. The content of salts in groundwater according to the reference data ${ }^{17}$ is on low level.

17 Greene R., Timms W., Rengasamy P., Arshad M., Cresswell R. Soil and Aquifer Stalinization. Toward an Integrated Approach for Salinity Management of Groundwater. 2008. URL: http://link.springer.com/chapter/10.1007/978-3-319-23576 


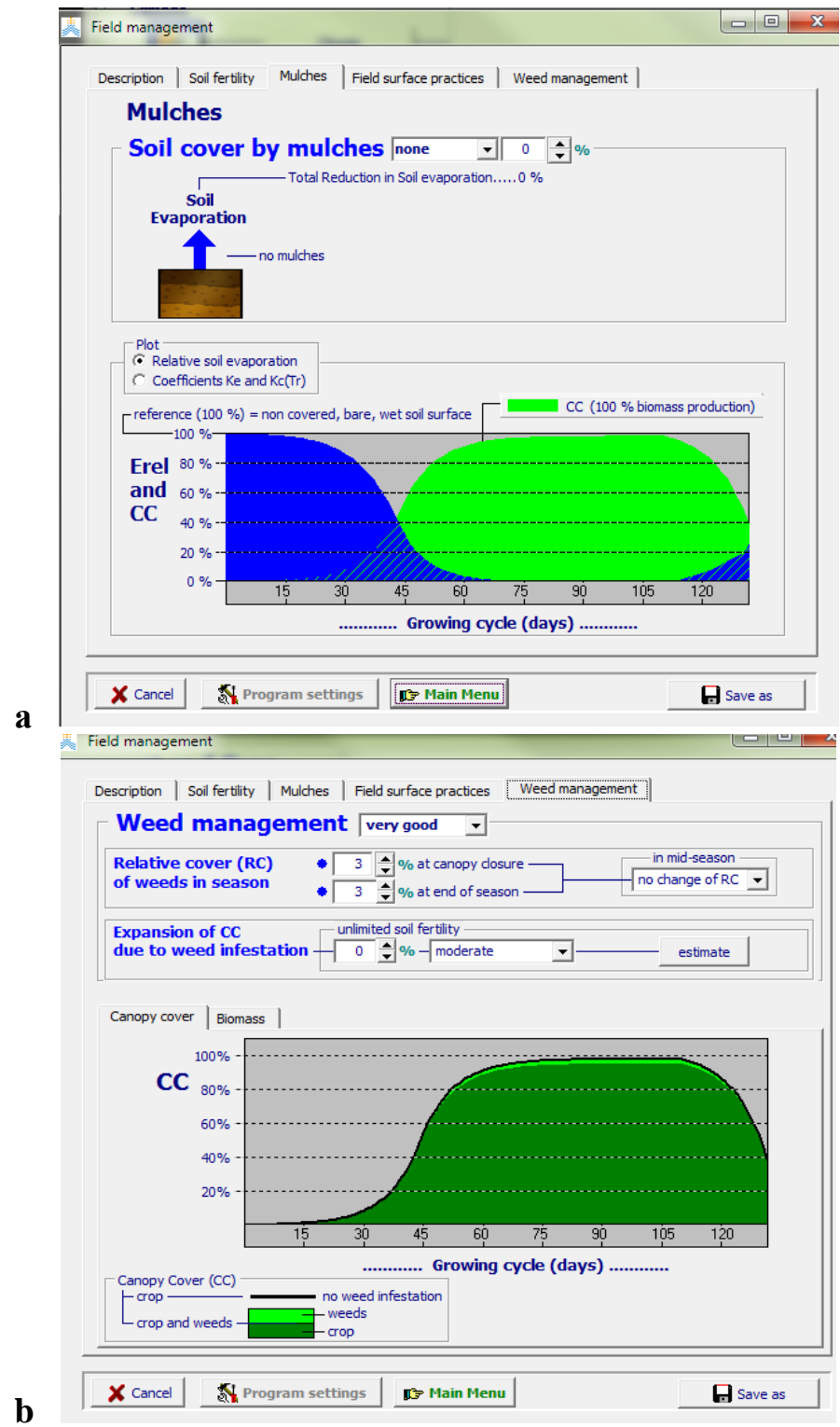

Fig. 2. A copy of the AquaCrop parameter selection screen with soil fertility (a) and weediness (b) crop management options 
At the beginning of the modeling, soil and water content were obtained by measuring them in the soil profile. Sampling was carried out on the day of sowing, and the beginning of the modeling period was recorded on the day of sowing.

The field capacity (FC) was determined at the level of $22.3 \%$ for dark-chestnut soil, wilting point $(9.75 \%)$, the TAW index was taken at the level of $80 \%$, since in the spring the soil is saturated with water, and this parameter is close to the FC level (Fig. 3), the electrical conductivity was accepted at the level of FAO statistical values for the middle-loamy soil $-1.5 \mathrm{dS} / \mathrm{m}^{18}$.

The modeling start date for the crop rotation crops such as corn, winter barley, soybean was adopted as their sowing dates at the experimental plots, it is, for example, May 3, September 20, May 10, 2015. After adapting the above mentioned indexes to the plan of a specific irrigation strategy, we chose the "automatic irrigation schedule" mode, the irrigation method was sprinkling according to time and depth criteria. Subsequently, simulation of the existing schedule of artificial humidification with different characteristics and variants of indexes of permissible reduction of soil moisture from the RAW - readily available water was carried out.

So, this parameter reflects the amount of moisture that the plant can easily uptake from the soil, it is found through the option "return to the level of the field capacity". The advantage of this irrigation mode is the normalization of irrigation schedules, which clearly take into account the dynamics of soil moisture content in the range from the field capacity (FC) to readily available water (RAW). In this case, water losses due to deep soaking are limited, and stresses from the lack of water supply and yield loss - are completely eliminated.

After forming the groups of Climate-Crop-Soil Moisture diagrams with quantitative characteristics of biomass and grain yields, we analyzed the optimal relationships between the input irrigation parameters and the modeling of the highest yield level with irrigation water used for each crop of the rotation.

${ }^{18}$ Wagner W., Lemoine G., Rott H. A Method for Estimating Soil Moisture from ERS Scatterometer and Soil Data. Remote Sens. Environ. 1999. Vol. 70. P. 191-207. 


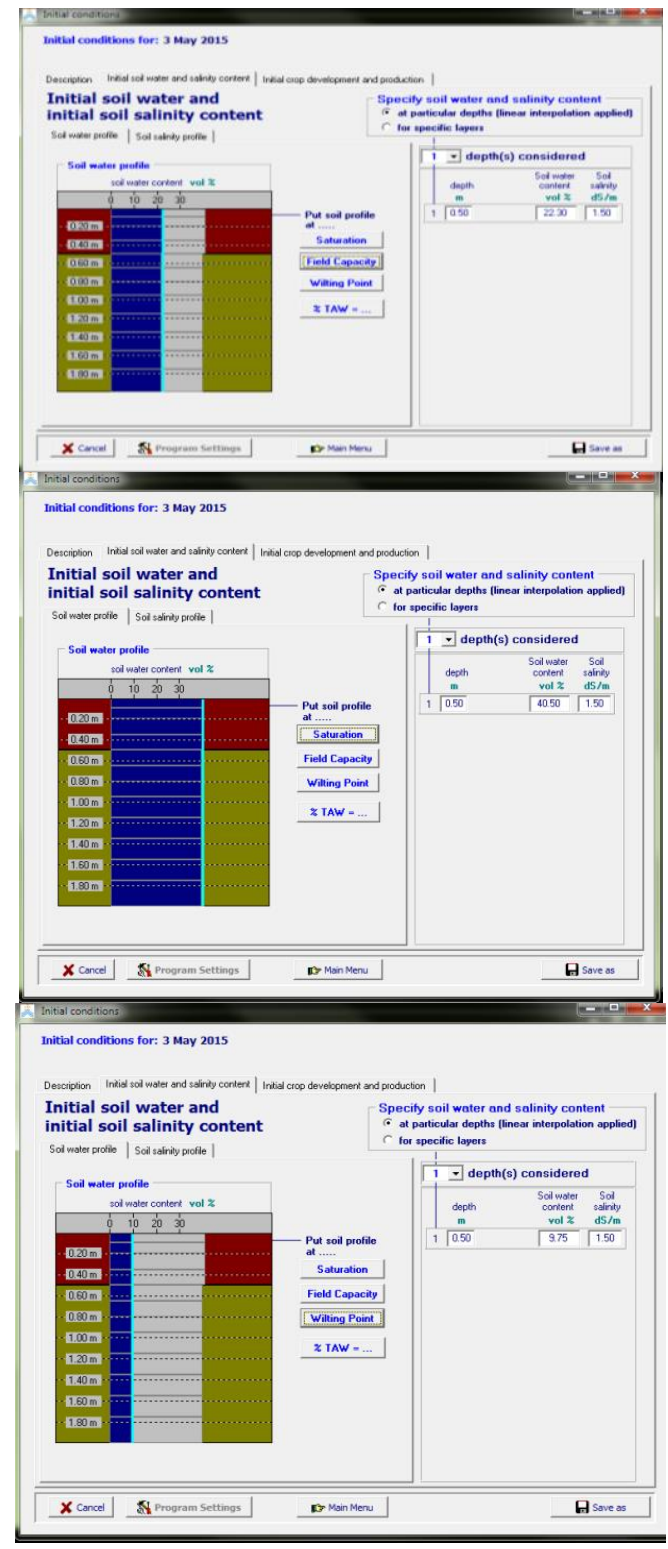

Fig. 3. Input conditions at the beginning of modeling of the productivity of short crop rotation in the AquaCrop program 
It is known that at the current level of development of irrigated agriculture, there are three main types of irrigation regimes biologically optimal, water-saving, soil-protective ${ }^{19}$. The AquaCrop program enables you to formulate irrigation schedules based on specific soil and climate and farming and economic factors, depending on the chosen irrigation strategy. In order to improve the productivity of short crop rotation at irrigation and economical use of irrigation water, we have chosen the strategy of forming both biologically optimal and water-saving irrigation regimes to show the possibilities of the program.

It should be emphasized that for corn with a predicted vegetation period of 132 days, the best scenario was with the programmed grain yield level of $14.16 \mathrm{t} / \mathrm{ha}$ (biomass $-29.49 \mathrm{t} / \mathrm{ha}$ ), for which the biologically optimal irrigation regime requires the use of $290 \mathrm{~mm}$ (it is equivalent to $2900 \mathrm{~m}^{3} / \mathrm{ha}$ ) (Fig. 4).

Modeling in the mode of so-called "scarce" irrigation (i.e. watersaving mode of irrigation) allowed to obtain a water-saving schedule of vegetation watering with the irrigation norm for the vegetative period of corn $-264.6 \mathrm{~mm}\left(2646 \mathrm{~m}^{3} / \mathrm{ha}\right)$. At the same time, the planned level of crop yield was $13.67 \mathrm{t} / \mathrm{ha}$ with the biomass yield $-28.33 \mathrm{t} / \mathrm{ha}$.

Thus, the conducted modeling made it possible to determine the difference between biologically optimal and water-saving irrigation regime. When applying the first irrigation regime, the maximum yield level was obtained, which was 0.49 t/ha or $3.6 \%$ higher than the second artificial humidification model. However, the water-saving scheme provided a reduction of irrigation norm by $254 \mathrm{~m}^{3} / \mathrm{ha}$ or $9.6 \%$.

The ratio between the actual soybean biomass obtained on the experimental plots and the stress-simulated ones for the period of the crop development under the biologically optimal irrigation regime was $96 \%$ and for the water-saving one $-92 \%$. Using similar technology, simulation models of yields, irrigation schedules and fertilizers for barley during the vegetation period from September 20 to July 1, 2015, were formed, which coincides with the modeling period.

19 Наукове обгрунтування та практична реалізація режимів зрошення сільськогосподарських культур 3 врахуванням природних та господарськоекономічних чинників : монографія [Р.А. Вожегова, Ю.О. Лавриненко, П.В. Писаренко та ін.]. Херсон: Грінь Д.С., 2015. 232 с. 


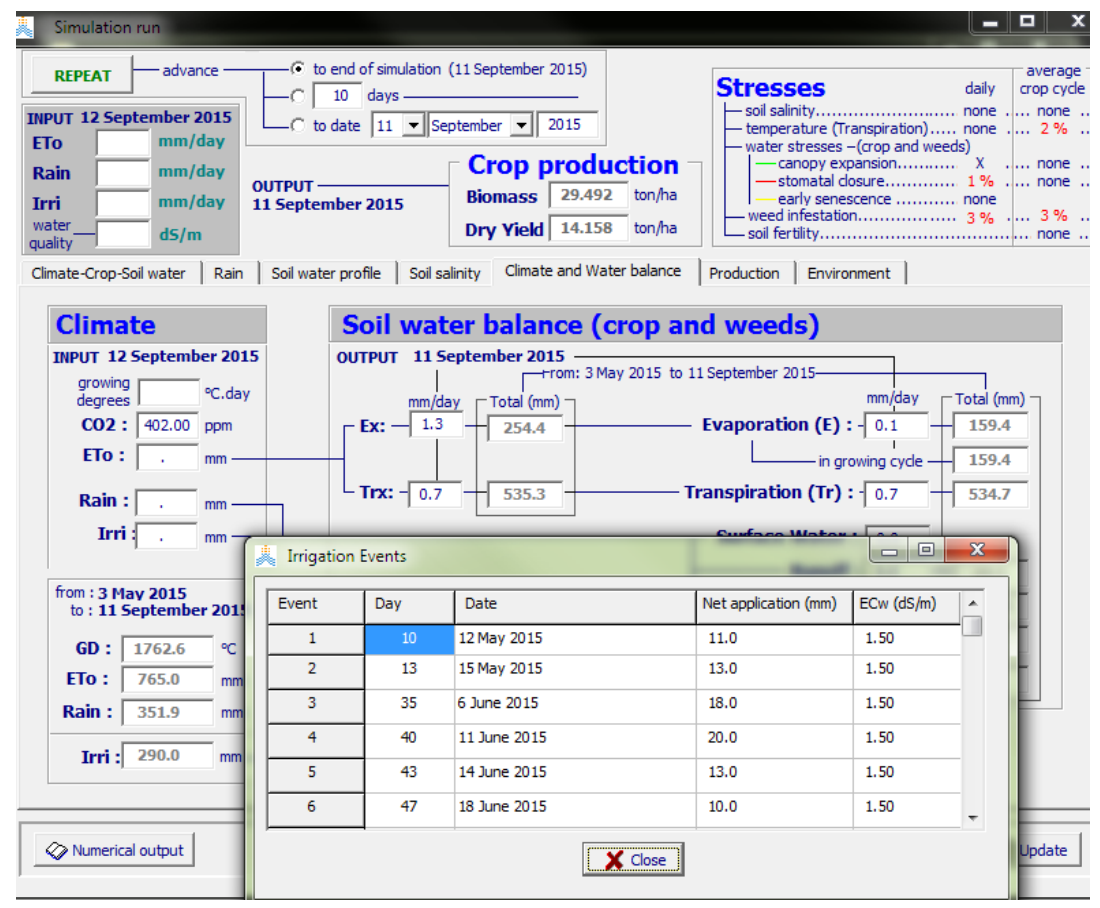

Fig. 4. Modeled indexes of biologically optimal regime of grain corn irrigation with accordance to the approximate dates and norms of vegetative watering

At the modeling of the water-saving regime of winter barley irrigation, it is proved that the estimated irrigation rate of $164 \mathrm{~mm}$ $\left(1640 \mathrm{~m}^{3} / \mathrm{ha}\right)$ should be used to compensate the water supply deficit during the vegetation period. Under such natural and technological conditions, the programmed yield was $4.19 \mathrm{t} / \mathrm{ha}$ (biomass $11.19 \mathrm{t} / \mathrm{ha}$ ). Continuing yield modeling, we have formed a biologically optimal irrigation regime under $80 \%$ of the permissible reduction of RAW with the irrigation norm of $2310 \mathrm{~m}^{3} /$ ha and the maximum grain yield of $4.43 \mathrm{t} / \mathrm{ha}$ (biomass of $11.85 \mathrm{t} / \mathrm{ha}$ ). The ratio between the actual obtained and the potential biomass of winter barley, taking into account the stresses during the period of the crop development under water-saving irrigation was $96 \%$, the yield index decreased to $37 \%$ (Fig. 5). 


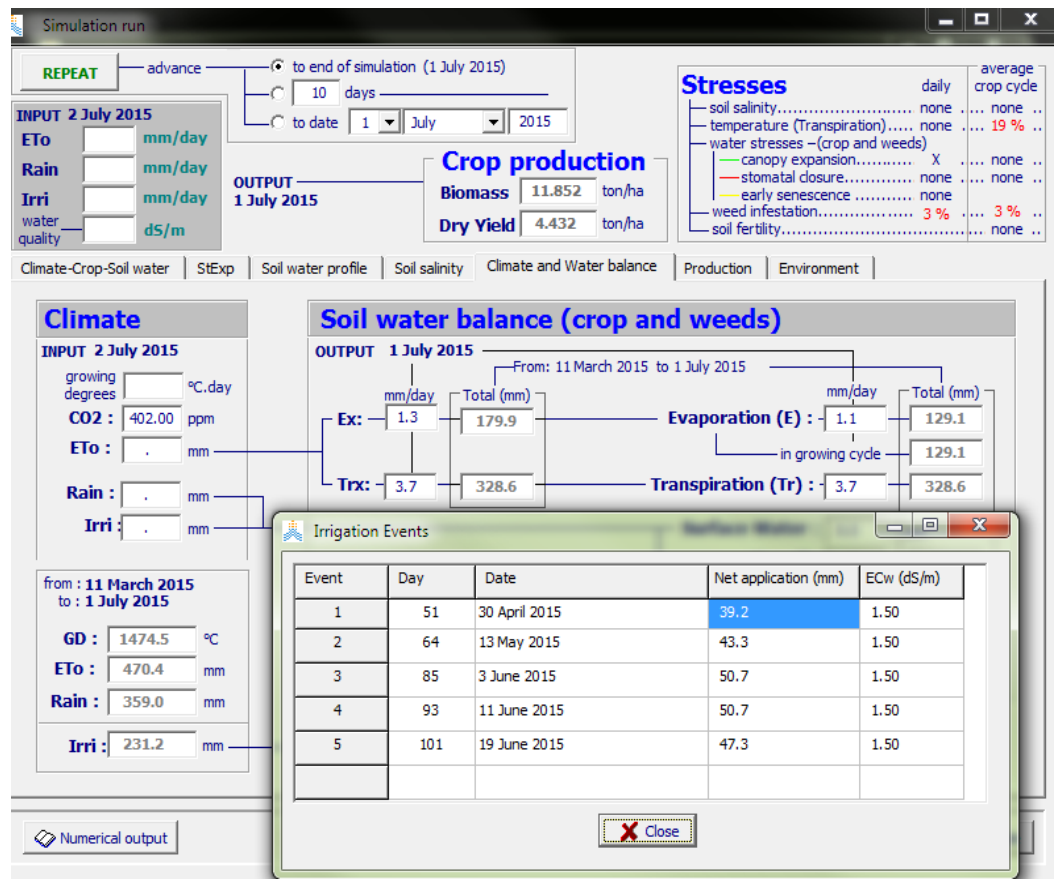

\section{Fig. 5. Biologically optimal schedule of winter barley irrigation for cultivation in short crop rotation at irrigation}

A very convinient tool of the AquaCrop program is that at every step of the modeling there is the possibility of controling the water and salt balance, nutrient content, taking into account the impact of all types of stress on a certain period of crop development in concrete stages of its growth and development, in the process of which can be reduced or completely overcomed various stresses by applying irrigation with the calculated norms, changing the sowing time, adjusting the plant density, differentiating doses of mineral fertilizers, etc. (Fig. 6).

At the modeling of the soybean irrigation regime, two technological scenarios of the regimes were developed - water-saving with irrigation norm of $3590 \mathrm{~m}^{3} /$ ha, programmable crop seed yield level of $4.7 \mathrm{t} / \mathrm{ha}$ (biomass $-11.7 \mathrm{t} / \mathrm{ha}$ ), as well as biologically optimal irrigation norm of $3830 \mathrm{~m}^{3} / \mathrm{ha}$, yield of $4.9 \mathrm{t} / \mathrm{ha}$ and biomass $12.2 \mathrm{t} / \mathrm{ha}$. 


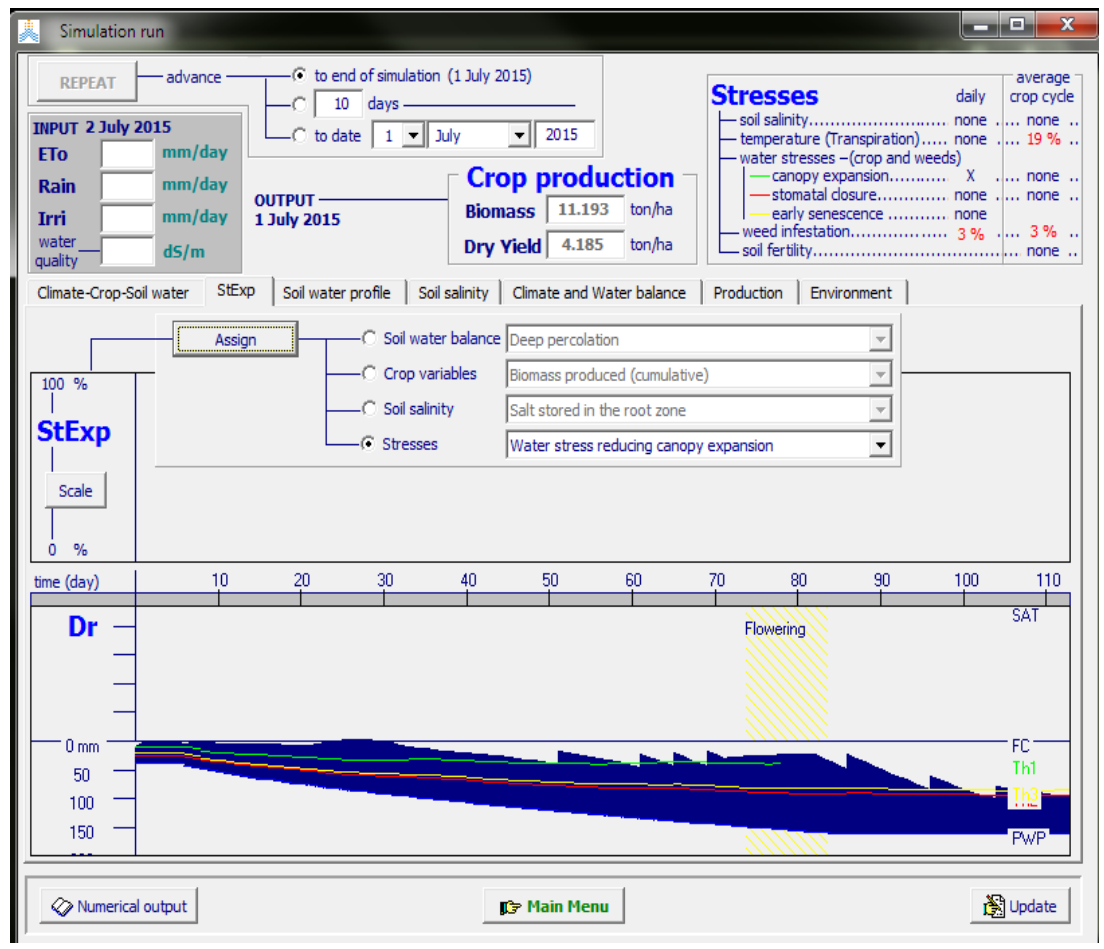

\section{Fig. 6. The regime of control and adjustment of the balances and stresses in the AquaCrop program toolkit}

The ratio between the actually obtained and the potential biomass of soybean under taking into account the influence of stresses during the vegetation period of the crop under the biologically optimal irrigation regime was $96 \%$ with a yield index of $39.3 \%$ (Fig. 7).

After the imitation modeling, it is possible to evaluate the results using the crop cover (CC) calculated data, aboveground biomass (B) and soil water content (SWC). All of this data is stored as databases in separate AquaCrop files.

After the modeling process is started, the AquaCrop software compares the modeled data with the field data and provides graphically the results in the following statistics:

- correlation coefficient of Pirson (r);

- mean square error (RMSE); 
- the usual correlation mean square error (CV (RMSE);

- the efficiency of the model (NF);

- Wilmouth range index (d).

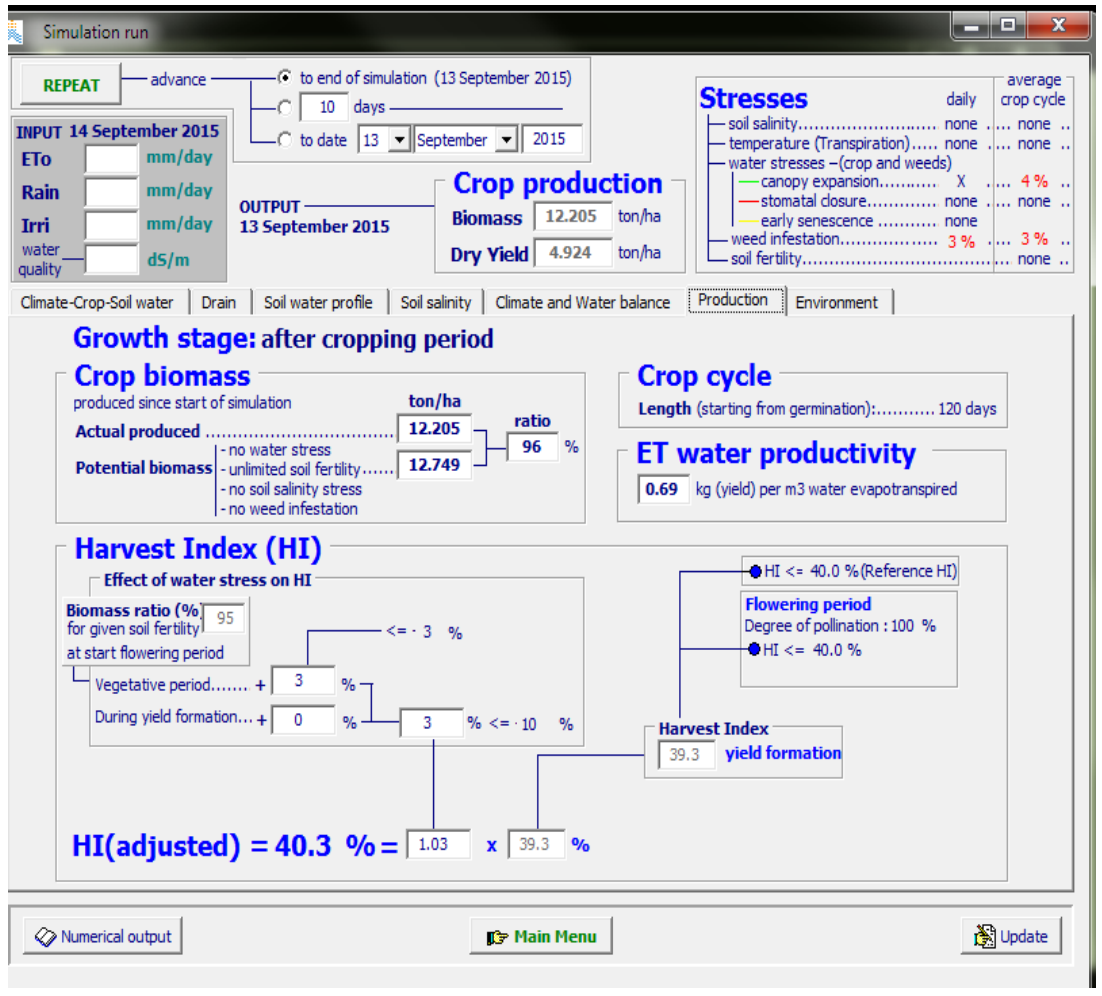

Fig. 7. Characteristics of biomass productivity, soybean yield index in the crop productivity modeling

The mathematical analysis of the program allows obtaining of dynamic reflection of the results of evaluation of the modeled (lines) and observed (points) data, and also to compare them with standard deviations (vertical lines) in the menu "Evaluation of the results of modeling" for crops of corn, winter barley and soybean. If we analyze the diagrams and metrics obtained from the experimental data, we can see that the modeling was performed with high mathematical accuracy. 


\section{CONCLUSIONS}

1. The application of special computer programs allows planning and optimizing both individual agro-technological operations and the whole integrated system of agriculture in irrigated lands of a particular farm with its unique natural climatic and farming and economic conditions. It is possible to schedule irrigation regimes, taking into account the parameters of irrigation schedules, methods of artificial moistening, time criteria, depth of soil wetting, and so on. Carrying out simulation modeling of irrigation schedules with different characteristics and variants allows optimizing the water, air and nutrient regimes of soil, prevent the loss of irrigation water through deep soaking and prevent the decrease in productivity of crops in short crop rotation due to the lack of water supply.

2. It is determined that in the developed short crop rotation the estimated level of soybean grain yield is about $4.9 \mathrm{t} / \mathrm{ha}$ with irrigation water consumption at the level of $3830 \mathrm{~m} 3 / \mathrm{ha}$, and the formation of irrigation schedule according to the water-saving scheme allows reduction of water consumption by $17 \%$. For corn, the potential grain yield is $-14.2 \mathrm{t} / \mathrm{ha}$, with the saving of irrigation water by $13 \%$, and for winter barley these figures are equal to $2.9 \mathrm{t} / \mathrm{ha}$ and $10 \%$, respectively.

3. By the results of our study, the functionality of the AquaCrop software and information complex has been adapted to the conditions of Southern Steppe of Ukraine. Using this program allows modeling of natural and agrotechnological factors, including irrigation regime at the level of short crop rotation, quickly and reliably estimate and choose the most economical variants of irrigation schedules for each crop with reduction of irrigation water consumption by $10-17 \%$, program yield on the basis of parameters of soil, a set of agrotechnological operations, characteristics of varieties and hybrids, changes in weather conditions, etc.

\section{SUMMARY}

The article presents the results of the study on the adaptation to the conditions of Southern Steppe of Ukraine the functionality of the AquaCrop software and information complex, developed by FAO scientists (2014-2017). Modeling of natural and agrotechnological factors, including irrigation regime at the level of short crop rotation, was carried out. The most economical variants of irrigation schedules 
for grain corn, soybean, winter barley and 10-17\% reduction of irrigation water consumption were quickly and accurately evaluated. The yield of these crops has been programmed on the basis of soil parameters, a set of agrotechnological operations, characteristics of varieties and hybrids, changes in weather conditions, etc. It was determined that for grain corn with a predicted vegetation period of 132 days, it is most advantageous to apply a scenario with a programmed grain yield level of $14.2 \mathrm{t} / \mathrm{ha}$ (biomass $-29.5 \mathrm{t} / \mathrm{ha}$ ), for the formation of which according to the biologically optimal regime the irrigation norm was $2900 \mathrm{~m} 3 / \mathrm{ha}$. Soybean productivity levels have also been modeled in two cultivation scenarios according to irrigation regimes - water-saving with irrigation norm of $3590 \mathrm{~m} 3 / \mathrm{ha}$, programmed grain yield of $4.7 \mathrm{t} / \mathrm{ha}$ and biomass $-11.7 \mathrm{t} / \mathrm{ha}$, biologically optimal with irrigation norm of $3830 \mathrm{~m} 3 / \mathrm{ha}$, yield of $4.9 \mathrm{t} / \mathrm{ha}$ and biomass $-12.2 \mathrm{t} / \mathrm{ha}$.

\section{REFERENCES}

1. Ahmadi H., Mosallaeepour E., Kamgar-Haghighi A.A. Modeling Maize Yield and Soil Water Content with AquaCrop Under Full and Deficit Irrigation Management. Published on the 28 of March 2016. URL: https://link.springer.com/article/10.1007/s11269-015-0973-3.

2. Вожегова Р.А., Лавриненко Ю.О., Коковіхін С.В., Писаренко П.В. та ін. Інструкція по оперативному розрахунку поливних режимів та прогноз поливів сільськогосподарських культур за дефіцитом вологозапасів: науково-методичні рекомендації. Херсон: ВЦ І33, 2012. 54 с.

3. Raes D., Steduto P., Hsiao T.C., Fereres E. AquaCrop training handbooks. Running AquaCrop. 2017. Book 2. Chapters 3-7. P. 19-61.

4. Adger N., Wreford A., Hulme M. Strategic Assessment of the Impacts, Damage Costs, and Adaptation Costs of Climate Change in Europe. Adaptation and Mitigation Strategies: Supporting European Climate Policy (ADAM project). Tyndall Centre for Climate Change Research. 2003. Technical Report № 7.20 p.

5. Fritz B. K., Kirk I. W., Hoffmann W. C., Martin D. E. Aerial application methods for increasing spray deposition on wheat heads. Applied Engineering in Agriculture American Society of Agricultural and Bigical Engineers. 2006. Vol. 22(3). P. 357-364. URL: http://ddr.nal.usda.gov/bitstream/10113/1926/1/ IND43877934.pdf. 
6. McCarthy N. Understanding agricultural households' adaptation to climate change and implications for mitigation: land management and investment options. Integrated Surveys on Agriculture. Washington D.C., USA: LEAD Analytics Inc. 2011. P. 42-47.

7. Milton C., Chamala S. Conservation Tillage and Cropping Innovation: Constructing the New Culture of Agriculture. Iowa State University Press. 2008. URL: http://onlinelibrary.wiley.com/ book/10.1002/9780470290149.

8. Araya A., Solomon H., Kiros M.H., Afewerk K., Taddese D. Test of AquaCrop model in simulating biomass and yield of water deficient and irrigated barley (Hordeum vulgare). Published on the 1 November 2010. URL: http://www.sciencedirect.com/science/ article/pii/ S037837741000226.

9. FAO IRRIGATION AND DRAINAGE PAPER by Pasquale Steduto (FAO, Land and Water Division, Rome, Italy) T. Hsiao (University of California, Davis, USA) Elias Fereres (University of Cordoba and IAS-CSIC, Cordoba, Spain) D. Raes (KU Leuven University, Leuven, Belgium). FOOD AND AGRICULTURE ORGANIZATION OF THE UNITED NATIONS. Rome, 2012. № 66. P. 70-85.

10. García-Vila M., Fereres E., Mateos L., Orgaz F., Steduto P. Deficit irrigation optimization of cotton with AquaCrop. Published on the 22 of May 2008. URL: https://dl.sciencesocieties.org/ publications/aj/abstracts/101/3/477.

11. Karlen D. L., Shannon M. C., Schneider S. M., Amerman C. R. Using Systems Engineering and Reductionist Approaches to Design Integrated Farm Management Research Programs. Jour. of Prod. Agric. 1994. Vol. 119. P. 144-151.

12. Steduto P., Hsiao T.C., Raes D., Fereres D. AquaCrop - The FAO Crop Model to Simulate Yield Response to Water: I. Concepts and Underlying Principles. Agr. Jour. 2009. Vol. 101(3). P. 26-37.

13. Raes D., Steduto P., HsiaoT.C., Fereres E. AquaCrop Reference manual. Running AquaCrop. 2012. Book 1. Version 4.0. Chapter 1-3. P. 1-39.

14. Drought-resistant soils optimization of soil moisture for sustainable plant production. Sales and marketing group FAO UN. Rome, Italy. 2007. 96 p. 
15. Архив погоды в Херсоне за период с 1 января 2005 года по 31 декабря 2016 года. URL: https://rp5.ru/Архив_погоды_в_ Херсон.

16. CROPWAT 8.0 for WINDOWS. URL: http://www.fao.org/nr/water/ infores_databases_cropwat.html.

17. Greene R., Timms W., Rengasamy P., Arshad M., Cresswell R. Soil and Aquifer Stalinization. Toward an Integrated Approach for Salinity Management of Groundwater. 2008. URL: http://link.springer.com/chapter/10.1007/978-3-319-23576.

18. Wagner W., Lemoine G., Rott H. A Method for Estimating Soil Moisture from ERS Scatterometer and Soil Data. Remote Sens. Environ. 1999. Vol. 70. P. 191-207.

19. Наукове обгрунтування та практична реалізація режимів зрошення сільськогосподарських культур 3 врахуванням природних та господарсько-економічних чинників : монографія [Р.А. Вожегова, Ю.О. Лавриненко, П.В. Писаренко та ін.]. Херсон: Грінь Д.С., 2015. 232 с.

\section{Information about the author: Markovska O. Ye.,} Doctor of Agricultural Sciences, Professor, Senior Researcher, Head of the Department of Botany and Plant Protection, State Higher Educational Establishment "Kherson State Agrarian University" 23, Stritenska str., Kherson, 73006, Ukraine 